\title{
Growth Performance of West African Dwarf (WAD) Sheep Fed Biodegraded Enterolobium cyclocarpum Based Diets
}

\author{
A. A. Ayuk¹, E. A. Iyayi², B. I. Okon'1, J. O. Ayuk ${ }^{3}$ \\ ${ }^{1}$ Department of Animal Science, University of Calabar, Calabar, Nigeria \\ ${ }^{2}$ Department of Animal Science, University of Ibadan, Ibadan, Nigeria \\ ${ }^{3}$ CRS Community and Social Development Agency, Calabar, Nigeria \\ Email: yinsajpcube2012@gmail.com
}

Received 31 March 2014; revised 23 June 2014; accepted 15 July 2014

Copyright (C) 2014 by authors and Scientific Research Publishing Inc.

This work is licensed under the Creative Commons Attribution International License (CC BY).

http://creativecommons.org/licenses/by/4.0/

(c) (i) Open Access

\section{Abstract}

The performance and economics of production of West African Dwarf (WAD) sheep was investigated in an experiment that lasted for 70 days. Twelve male sheep averaging $9.9 \mathrm{~kg}$ in liveweight and aged 7 - 9 months were randomly assigned to four treatment groups in a completely randomized design with three animals per treatment. Chemical composition of diets, intake, liveweight gain and cost implication of feeding WAD sheep with grass, a conventional concentrate, an autoclaved and biodegraded Enterolobium cyclocarpum based diet were determined. The crude protein content of Guinea grass $(4.43 \%)$ was relatively low compared to that of biodegraded Enterolobium cyclocarpum (14.13\%). Total consumption and liveweight change were not significantly different $(P<0.05)$. The growth rate of animals fed concentrates were significantly $(P<0.05)$ higher than those on the grass diet. Cost per $\mathrm{Kg}$ of feed was the highest for control and least for guinea grass diet. However, cost per unit gain was the highest for Guinea grass diet ( $\mathrm{N}$ 176.73) and least for biodegraded Enterolobium cyclocarpum diet ( $\mathrm{N}$ 72.62). It was cheaper to produce 1 kg mutton using biodegraded EC diets than control, autoclaved and guinea grass diets respectively. The results suggest that biodegrading of Enterolobium cyclocarpum improved its nutrient quality, utilization and the performance and economy of production of West African Dwarf sheep.

\section{Keywords}

Enterolobium cyclocarpum, Anti Nutritonal Factors, West African Dwarf Sheep, Growth 


\section{Introduction}

Multipurpose trees (MPTs) which are generally richer and maintain a higher nutrient quality than grasses throughout the year, constitute an important feed resource in ruminant nutrition. The tree and shrub legume forages are rich in most essential nutrients such as proteins and minerals and tend to be more digestible than grasses and crop residues [1]. According to [2], browse plants are available in the off season but most of them are less beneficial to livestock as they contain antinutritional factors. Enterolobium cyclocarpum is a tropical multipurpose tree whose leaves contain the antinutritonal factor saponin [3], tannins, phytate and oxalates [4]. It is a Central American native species that grows in central Mexico, from the Pacific Ocean coasts and the Gulf of Mexico to the North of Brazil and Columbia [5]. It has defaunating properties [6] and the heartwood extracts have dissuasive effects on termites [7]. In the south western Nigeria, Enterolobium cyclocarpum foliage has not been accepted by sheep, goats and cattle possibly due to the presence of antinutritional factors [2].

Fermentation is one of the oldest applied biotechnologies, having been used in food processing and preservation as well as beverages production for over 6000 years [8]. Biological treatments of lignocellulosic substrates include cultivation with specific fungi capable of producing a spectrum of lignin and cellulose-degrading enzymes during solid state fermentation [9]. However, forage quality and overall potential are best measured in terms of animal productivity [10]. The purpose of this study was to appraise the effects of biodegrading Enterolobium cyclocarpum with Aspergillus niger on improving its utilization by WAD sheep.

\section{Materials and Methods}

The study was conducted at the Teaching and Research farm of the University of Ibadan, Ibadan. Leaves of Enterolobium cyclocarpum were obtained from an established plot in Wasimi village, South Western Nigeria. Sun dried leaves were ground, autoclaved and allowed to cool. A portion was saved for inoculation with Aspergillus niger. The fungi were grown on potato dextrose broth and harvested into ground damp autoclaved EC in sterile plastic bowls. At the end of incubation, samples were oven-dried. Biodegraded EC gave fishmeal-like aroma as against choking and peppery smell of ground dry undegraded EC. The smell of the autoclaved EC was also choking but less than undegraded oven-dried samples. Twelve male West African Dwarf sheep, average weight $9.9 \mathrm{~kg}$ and age 7 - 9 months were randomly assigned to four experimental treatment groups in a completely randomized design with three animals per treatment. Grass and concentrates (Table 1) were fed separately, with grass serving as basal ration. The sole grass diet was served, allowing $20 \%$ increase of dry matter consumed the previous day. Feed was offered twice daily (08.00 and $16.00 \mathrm{hrs}$ ) while animals were weighed once weekly. All

Table 1. Composition of experimental concentrate diets.

\begin{tabular}{cccc}
\hline & \% DM & & \\
\hline Ingredients & Control (1) & $\begin{array}{c}\text { Autoclaved Enterolobium } \\
\text { cyclocarpum (2) }\end{array}$ & $\begin{array}{c}\text { Biodegraded Enterolobium } \\
\text { cyclocarpum (3) }\end{array}$ \\
\hline Cassava flour & 28 & 34 & 35 \\
Wheat Offal & 18 & - & 10 \\
Corn bran & 16 & 10 & 17 \\
PKC & 16 & 17 & 5 \\
Cottonseed cake & 8 & 5 & 4 \\
Groundnut cake & 5 & 5 & 3 \\
Bone meal & 5 & 5 & 1 \\
Ground Oyster shell & 3 & 3 & - \\
Salt & 1 & 20 & - \\
\hline
\end{tabular}


animals were quarantined before the feeding trial and had ad libitum access to water. The experiment lasted for 70 days (8 weeks). Ground dry samples of Guinea grass and other supplemental diets were analysed for their contents of Ca, Mg, K, Fe, P and CP (Nx 6.25) using methods of [11]. Data were analysed by the analysis of variance procedures of SAS [12], results were expressed as means of three replicates. Significant differences were compared using the Duncan Multiple Range Test at $\mathrm{P}<0.05$.

\section{Results and Discussion}

The proximate composition of the experimental diets is presented in Table 2. The crude protein of the Guinea grass (4.43\%) is relatively low compared to the biodergraded Enterolobium cyclocarpum (14.13\%).

The crude protein content of the biodegraded EC diets being higher than that of the autoclaved EC diet suggest the improvement in contents by fungal action. Treatment with white-rot fungi increased the nutritive value of straw [13] [14]. Though autoclaving might have effect on materials, action of the fungus on the autoclaved EC may have resulted to increased protein. Wheat straw treated with Pleurotus ostreatus and Trametes versicolor had increased CP and decreased organic carbon and C/N ratio as compared with untreated wheat straw [9]. [15] reported reduced crude fibre, ether extract, crude protein, and acid detergent fibre and nitrogen content of Albizia, as a result of autoclaving. The NDF values of the biodegraded EC were higher suggesting breakdown of autoclaved fibre by fungus. The removal of lignin and/or hemicellulose can substantially increase the susceptibility of biomass to enzymatic hydrolysis [16]. It has been previously shown that white-rot fungi can degrade crop residues during solid state fermentation as a result of action by carbohydrases (Cellulases and xylanases) and oxidative ligninolytic enzymes including lignin peoxidases, manganese peroxidise and lacase [17] [18]. Intake of Guinea grass, other concentrates and live weight gains of the sheep are presented in Table 3 . The growth rate of animals fed concentrates were significantly $(\mathrm{P}<0.05)$ different from grass diets. Intake of Guinea grass was higher for sole-grass fed animals but not twice as much as consumed by animals on grass and concentrate diets. [10] reported that animals on sole grass diets consumed twice as much grass than animals on mixed grass legume. Sheep on biodegraded EC diets consumed more concentrate than those on control and autoclaved EC diets, respectively. The high consumption suggests the improved nutritional and sensory value of the feed resulting from biodegradation. On the other hand, the choking odour of autoclaved Enterolobium cyclocarpum may have affected its palatability, hence, its being less consumed. However, the animals on the autoclaved EC diets consumed more grass than others on concentrate.

Table 2. Chemical composition of experimental diets.

\begin{tabular}{ccccc}
\hline & \multicolumn{3}{c}{ \% DM } & \\
\hline Ingredients & Control & $\begin{array}{c}\text { Autoclaved Enterolobium } \\
\text { cyclocarpum }\end{array}$ & $\begin{array}{c}\text { Biodegraded Enterolobium } \\
\text { cyclocarpum }\end{array}$ & Guinea grass \\
\hline Dry matter & 92.36 & 91.62 & 91.42 & 18.83 \\
Crude protein & 11.06 & 10.31 & 14.13 & 4.43 \\
Ether extract & 3.58 & 4.14 & 3.52 & 24.24 \\
Crude fibre & 11.80 & 12.62 & 7.08 & 9.48 \\
Ash & 17.68 & 26.86 & 22.30 & 74.64 \\
NDF & 31.40 & 29.96 & 35.08 & 39.48 \\
ADF & - & - & - & 0.33 \\
Ca & 1.49 & 2.29 & 2.18 & 0.006 \\
Mg & 0.51 & 0.42 & 0.39 & 0.06 \\
K & 1.45 & 1.16 & 1.32 & - \\
P & 0.95 & 0.56 & 0.90 & 124.78 \\
Fe (ppm) & 137.56 & 152.22 & 189.97 &
\end{tabular}


Table 3. Performance characteristics of West African Dwarf sheep fed conventional concentrate diet, autoclaved Enterolobium cyclocarpum, biodegraded Enterolobium cyclocarpum based diets and guinea grass.

\begin{tabular}{ccccc}
\hline & Diets & & & \\
\hline Parameter & Control & $\begin{array}{c}\text { Autoclaved Enterolobium } \\
\text { cyclocarpum }\end{array}$ & $\begin{array}{c}\text { Biodegraded Enterolobium } \\
\text { cyclocarpum }\end{array}$ & Guinea Grass \\
\hline Initial Lw (Kg) & 9.7 & 9.8 & 9.6 & 10.5 \\
Intake g DM per day guinea grass & 71.78 & 74.07 & 71.52 & 94.69 \\
Intake g DM per day concentrates & 1.67 & 1.36 & 1.79 & $94.69^{\mathrm{a}}$ \\
Total intake g DM per day & $73.45^{\mathrm{a}}$ & $75.43^{\mathrm{a}}$ & $73.31^{\mathrm{a}}$ & $3.1^{\mathrm{b}}$ \\
Live weight gain (Kg) & $2.7^{\mathrm{b}}$ & $2.4^{\mathrm{b}}$ & $3.1^{\mathrm{b}}$ & $19.60^{\mathrm{c}}$ \\
\hline Growth rate (g/day) & $48.21^{\mathrm{b}}$ & $42.86^{\mathrm{b}}$ & $55.36^{\mathrm{b}}$ & \\
\hline
\end{tabular}

Table 4. Production cost economics.

\begin{tabular}{|c|c|c|c|c|}
\hline & Diets & & & \\
\hline Parameters & Control & $\begin{array}{l}\text { Autoclaved Enterolobium } \\
\text { cyclocarpum }\end{array}$ & $\begin{array}{l}\text { Biodegraded Enterolobium } \\
\text { cyclocarpum }\end{array}$ & Guinea Grass \\
\hline Total feed consumed (Kg) & 84.34 & 85.11 & 84.57 & 99.85 \\
\hline Weight gain (Kg) & 2.73 & 2.4 & 3.13 & 1.13 \\
\hline 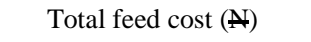 & 244.24 & 214.99 & 227.29 & 199.71 \\
\hline 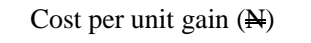 & 89.47 & 89.56 & 72.62 & 176.73 \\
\hline Feed per unit gain $(\AA)$ & 30.89 & 35.63 & 26.95 & 88.36 \\
\hline
\end{tabular}

Several reports indicate that supplementation of basal grass diets improves feed intake and liveweight gains [19] [20]. The liveweight changes in this study were higher for biodegraded EC diets but not significantly different from the grass diet which had least liveweight gain.

The costs of experimental diets are given in Table 4. Cost per Kg of feed was highest for control and least for guinea grass diet. However, cost per unit gain was highest for guinea grass diet ( 176.73 ) and least for biodegraded EC diet ( 72.62).

The supplementation of Guinea grass with concentrates improved the efficiency of utilization and agrees with reports of [21] and [15]. In this study, cost of production was evaluated as that would show returns on investment. Although animals on control diets had highest total feed cost followed by biodegraded EC, the cost per unit tells better how much of investment would translate into mutton. In that regard, it was cheaper to produce one kilogram of mutton using biodegraded EC, compared to control, autoclaved EC and grass diets, respectively. Similarly, less of the biodegraded EC diet is required to produce the same amount of gain when compared to control, autoclaved and Guinea grass based diets respectively.

\section{Conclusion}

Results suggest that inoculation of Enterolobium cyclocarpum with Aspergillus niger is effective in enhancing nutrient quality, increasing intakes and liveweight gain thereby making fungal biodegradation a simple and cheaper alternative in improving the use of MPTs as fodder for small ruminants.

\section{Acknowledgements}

The authors are most grateful to Professor O.M. Arigbede for the establishment of the Enterolobium cyclocarpum arboretum. 


\section{References}

[1] Njidda, A.A. and Olatunji, E.A. (2012) Chemical Composition, Anti Nutritive Substances and in Situ Digestion Kinetics of Four Ziziphus Species Leaves Use as Fodder for Ruminants in Semi Arid Zone of Nigeria. Journal of Natural Sciences Research, 2, 79-87.

[2] Babayemi, O.J. (2006) Antinutritional Factors, Nutritive Value and in Vitro Gas Production of Folliage and Fruit of Enterolobium cyclocarpum. World Journal of Zoology, 1, 113-117.

[3] Oni, A.O., Onwuka, C.F.I., Oduguwa, O.O., Onifade, O.S., Arigbede, O.M. and Olatunji, J.E.N. (2006) Utilization of Citrus Pulp Based Diet and Enterolobium cyclocarpum Foliage (Jacq. Griseb) by West African Dwarf Goats. Journal of Animal and Veterinary Advances, 5, 814-818.

[4] Ayuk, A.A., Iyayi, E.A. and Okon, B.I. (2008) Solid Substrate Fermentation of Ground Leaves of Pterocarpus santalinoides with Two Isolates of Aspergillus niger. Proceedings of the 33rd Annual Conference of the Nigerian Society of Animal Production, Olabisi Onabanjo University, March 2008, 243-245.

[5] Martinez Pacheco, M.M., Del Rio, R.E.N., Flores Garcia, A., Martinez Muňoz, R.E., Ron Echeverria, O.A. and Raya Gonzallez, D. (2012) Enterolobium cyclocarpum (jacq) Griseb: The Biotechnology Profile of a Tropical Tree. Blacpma, 11, 385-399.

[6] Koenig, K.M., Ivan, M., Teferedegne, B.T., Morgavi, D.P., Rode, L.M., Ibrahim, I.M. and Newbold, C.J. (2007) Effect of Dietary Enterolobium cyclocarpum on the Microbial Protein Flow and Nutrient Digestibility in Sheep Maintained Fauna-Free, with Total Mixed Fauna or with Entodinium caudatum Monoflora. British Journal of Nutrition, 98, 504516. http://dx.doi.org/10.1017/S0007114507723930

[7] Raya-Gonzalez, D., Martinez Muňoz, R.E., Ron Echeverria, O.A., Flores Garcia, A., Macias-Rodriguez, L.I. and Martinez Pacheco, M.M. (2013) Dissuasive Effect of an Aqueous Extract from Enterolobium cyclocarpum (Jacq) Griseb on the Drywood Termite Incisitermes marginipennis (Isoptera: Kalotermitidae) (Latrelle). Emirate Journal of Food and Agriculture, 25, 524-530.

[8] Motarjemi, Y. (2002) Impact of Small Scale Fermentation Technology on Food Safety in Developing Countries. International Journal of Food Microbiology, 75, 213-229. http://dx.doi.org/10.1016/S0168-1605(01)00709-7

[9] Ramirez-Bribiesca, J.E., Wang, Y., Lin, L., Canam, T., Town, J.R., Tsang, A., Dumonceaux, T.J. and McAllister, T.A. (2011) Chemical Characterisation and in Vitro Fermentation of Brassica Straw Treated with the Aerobic Fungus, Trametes versicolor. Canadian Journal of Animal Science, 91, 695-702. http://dx.doi.org/10.4141/cjas2011-067

[10] Bamikole, M.A., Ezenwa, I., Akinsoyinu, A.O., Arigbede, M.O. and Babayemi, O.J. (2000) Performance of West African Dwarf Goats Fed Guinea Grass-Veranostylo Mixture, N-Fertulized and Unfertilized Guinea Grass. Small Ruminant Research, 39, 145-152. http://dx.doi.org/10.1016/S0921-4488(00)00182-6

[11] A.O.A.C. (1990) Methods of Analysis. 15th Edition, Association of Official Analytical Chemists, Washington D.C., 1121-1180.

[12] SAS (1988) Statistical Analytical Systes Institute, SAS/STAT Users Guide, Release 6.03. Cary NC.

[13] Tripathi, M.K., Mishra, A.S., Mishra, A.K., Vaithiyanathan, S., Prasad, R. and Jakhmola, R.C. (2008) Selection of White-Rot Basidiomycetes for Bioconversion of Mustard (Brassica compestris) Straw under Solid-State Fermentation into Energy Substrate for Rumen Micro-Organisms. Letters in Applied Microbiology, 46, 364-370. http://dx.doi.org/10.1111/j.1472-765X.2008.02320.x

[14] Shrivastava, B., Tukur, S., Pul Khasa, Y., Gupte, A., Puniya, A.K. and Kuhad, R.Ch. (2010) White-Rot Fungal Conversion of Wheat Straw to Energy Rich Cattle Feed. Biodegradation, 22, 823-831. http://dx.doi.org/10.1007/s10532-010-9408-2

[15] Adebiyi, B.A. and Adeneye, J.A. (2001). Effects of Albizia samen Pods Supplementation on Feed Intake and Live Weight Changes of White Fulani Calves. Nigerian Journal of Animal Production, 28, 68-71.

[16] Yu, H., Zhang, X., Song, L., Ke, J., Xu, C., Du, W. and Zhang, J. (2010). Evaluation of White-Rot Fungi-Assisted Alkaline/Oxidative Pretreatment of Corn Straw Undergoing Enzymatic Hydrolysis by Cellulose. Journal of Bioscience and Bioengineering, 110, 660-664. http://dx.doi.org/10.1016/j.jbiosc.2010.08.002

[17] Nyanhongo, G.S., Gomes, J., Gubitz, G., Zvauya, R., Read, J.S. and Steiner, W. (2002) Production of Laccase by a Newly Isolated Strain of Trametes modesta. Bioresource Technology, 84, 259-263. http://dx.doi.org/10.1016/S0960-8524(02)00044-5

[18] Singh, P., Sulaiman, O., Hashim, R., Rupani, P.F. and Cheu, P. (2010) Biopulping of Lignocelluloses Material Using Different Fungal Species. A Review. Reviews in Environmental Science and Biotechnology, 9, 141-151.

[19] Mosi, A.K. and Butterworth, M.H. (1985) The Voluntary Intake and Digestibility of Combination of Cereal Crop Residues and Legume Hay for Sheep. Animal Feed Science and Technology, 12, 241-251. http://dx.doi.org/10.1016/0377-8401(85)90001-X 
[20] Akinusi, F.A.O. and Adeleye, I.O.A. (1998) Response of West African Dwarf Ewes to Premating Concentrate Supplementation. Proceedings of the 3rd Annual Conference of Animal Science Association of Nigeria, Ikeja, 16-17 September 1997, 126-127.

[21] Aina, A.B.J. (1996) Performance of Female W.A.D. Goats Fed Spondias mombin Plus Concentrate. Nigerian Journal of Animal Production, 23, 161-163. 
Scientific Research Publishing (SCIRP) is one of the largest Open Access journal publishers. It is currently publishing more than 200 open access, online, peer-reviewed journals covering a wide range of academic disciplines. SCIRP serves the worldwide academic communities and contributes to the progress and application of science with its publication.

Other selected journals from SCIRP are listed as below. Submit your manuscript to us via either submit@scirp.org or Online Submission Portal.
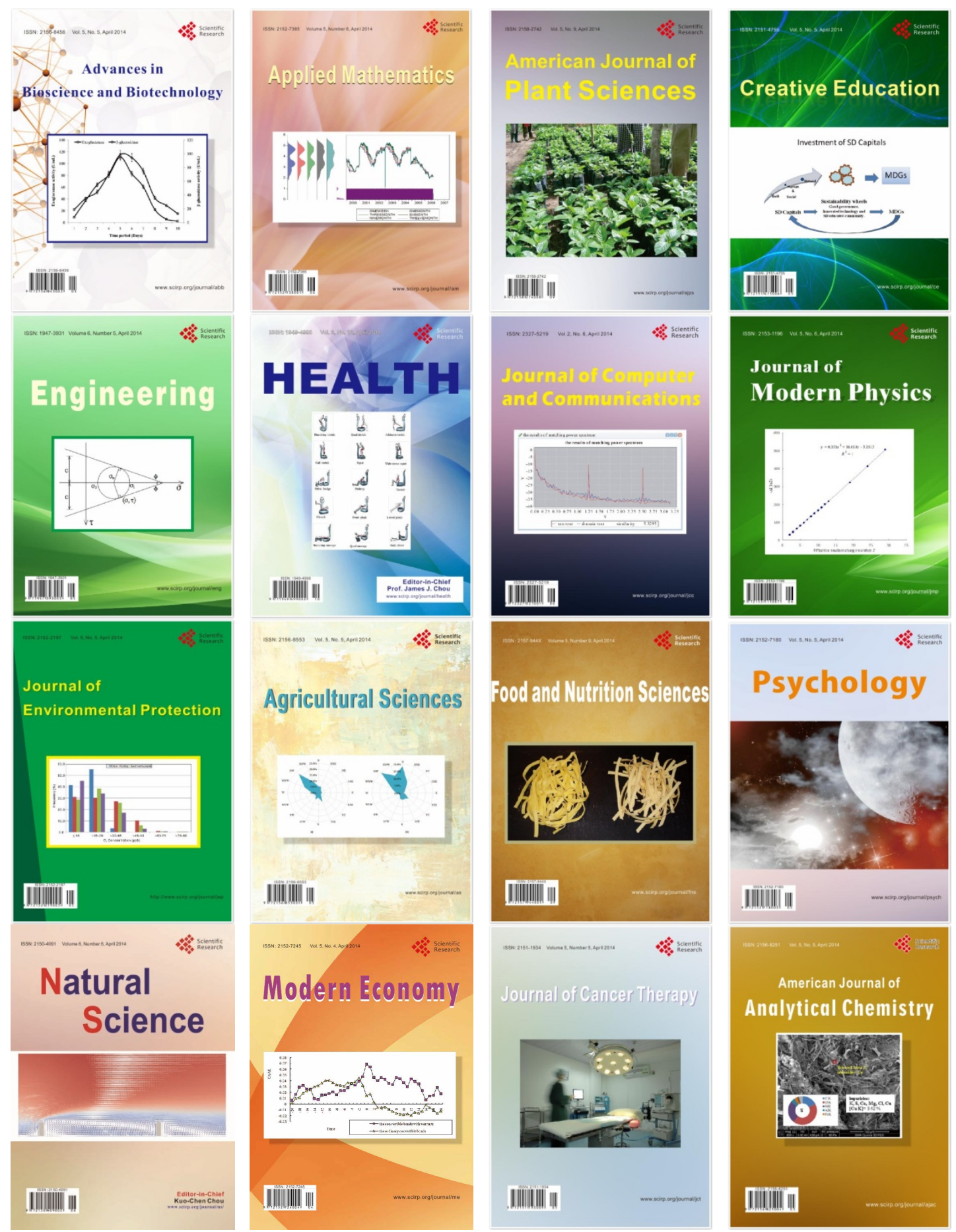